\title{
Peran Orang Tua dalam Mengembangkan Kecerdasan Emosional Anak
}

\author{
Meriyati \\ Dosen Fakultas Tarbiyah dan Keguruan, IAIN Raden Intan Lampung \\ Diterima: April 2014. Disetujui: Mei 2014. Dipublikasikan: Juni 2014
}

\begin{abstract}
Abstrak: Salah satu upaya yang dapat dilakukan adalah dengan mempersiapkan kecerdasan kognitif maupun kecerdasan emosiona. Kecerdasan emosional ini lebih ditujukan pada upaya mengenali, memahami dan mewujudkan emosi dalam porsi yang tepat serta upaya untuk mengelola emosi agar terkendali sehingga dapat dimanfaatkan untuk memecahkan berbagai permasalahan yang dihadapi kelak. Melalui IQ orang dapat menghadapi dunia nyata, tetapi individu membutuhkan emosi agar dapat memahami dan menghadapi dirinya sendiri dan akhrnya dapat menghadapi orang lain, begitu pentingnya kita membangun kecerdasan emosional anak untuk persiapannya kedepan kelak. Dengan memiliki kecerdasan emosi seseorang akan lebih memahami dan menghargai perasaan pada diri dan orang lain serta dapat menerapkannya secara efektif dalam kehidupannya sehari-hari.
\end{abstract}

Kata Kunci : peran orang tua, kecerdasan emosional anak

\section{Pendahuluan}

Kapasitas kecerdasan anak dimulai sejak usia dini. Jauh di bawah usia sekolah. Hasil penelitian Depdiknas menyebutkan pada usia 4 tahun, kecerdasan anak mencapai 50 persen. Sedangkan pada usia 8 tahun kapasitas kecerdasan anak yang sudah terbangun mencapai 80 persen. Tetapi kecerdasan baru mencapai kesempurnaan ketika anak berusia 18 tahun. Selain kecerdasan intelektual yang pada mulanya sangat diangungkan, ternyata manusia memiliki juga kecerdasan emosional yang turut menentukan keberhasilan seseorang dalam hidupnya (Goleman, 2000). Daniel Goleman adalah tokoh yang mempopulerkan keberadaan kecerdasan emosional. Mengembangkan keerdasan emosional anak, sangat perlu, pendidikan anak dini usia merupakan investasi untuk menyiapkan generasi penerus yang sehat, cerdas, dan ceria. Betapa pentingya pendidikan prasekolah tetapi nampaknya pendidikan usia dini justru belum banyak mendapat perhatian dari berbagai pihak. Dari aspek pendidikan, stimulan dini sangat diperlukan guna memberikan rangsangan terhadap seluruh aspek perkembangan anak termasuk kecerdasan emosional anak.

Semua manusia memiliki kecerdasan intelektual dan kecerdasan emosional, tapi tidak ada dua orang yang sama, walau kembar sekalipun, dan ini terjadi berkat pengaruh genetik dan lingkungan yang berbeda pada setiap orang. Walaupun begitu, anak yang cerdas tidak hanya ditandai dengan cerdas kognitif (IQ). Tanpa kecerdasan emosional (EQ), anak sulit mengembangkan kepribadiannya (Gardner, 1993). Anak dengan kecerdsaan emosional yang tinggi adalah anak-anak yang bahagia, percaya diri, memiliki kesadaran diri, pengaturan diri, motivasi diri, empati. Mereka lebih mampu menguasai gejolak emosinya, menjalin hubungan yang manis dengan orang lain, bisa mengatasi stres, dan memiliki kesehatan mental yang baik. kecerdasan emosional diperlukan untuk mengatasi berbagai masalah dalam hidup ini dan menjadi dasar untuk menjadi manusia dewasa yang bertanggung jawab.

\section{Metode Penelitian}

Metode penelitian ini dilakukan dengan deskriptif kualitatif. Dalam tulisan ini menggunakan studi pustaka atau menggali data dari library research untuk memperkaya khasanah keilmuan bimbingan dan konseling. 


\section{Hasil dan Pembahasan}

Kecerdasan Emosional adalah kemampuan seseorang untuk memahami dan mengelola perasaannya sendiri dan orang lain, dan menggunakan informasi tersebut sebagai pedoman untuk mempersiapkan kepada yang lebih baik, membuat keputusan yang lebih baik, berpikir lebih kreatif, memotivasi diri sendiri dan orang lain, dan menikmati kesehatan yang lebih baik, hubungan yang lebih baik dan kehidupan yang lebih bahagia. Emotional Intelligence (EI) sering diukur sebagai Emotional Intelligence Quotient (EQ). Social and emotional learning (SEL) adalah proses belajar untuk mencapai kecerdasan emosional yang lebih tinggi. Studi menunjukkan bahwa kecerdasan emosional adalah alat prediksi terbaik dari prestasi masa depan anak; lebih baik daripada faktor apa pun. Sebagian orang mengatakan bahwa kecerdasan emosional adalah alat prediksi yang lebih baik atas kesuksesan daripada IQ atau kombinasi keterampilan tekhnis.

Steiner menjelaskan bahwa kecerdasan emosi adalah suatu kemampuan yang dapat mengerti emosi diri sendiri dan orang lain, serta mengetahui bagaimana emosi diri sendiri terekspresikan untuk meningkatkan maksimal etis sebagai kekuatan pribadi. Senada dengan definisi tersebut, Mayer dan Solovey dalam Goleman, mengungkapkan kecerdasan emosi sebagai kemampuan untuk memantau dan mengendalikan perasaan sendiri dan orang lain, dan menggunakan perasaan-perasaan itu untuk memadu pikiran dan tindakan (Salovey \& Mayer, 2004).

Oleh karena itu, seseorang yang mempunyai kecerdasan emosional adalah seseorang yang menyadari emosinya sendiri dan emosi orang lain dan menyesuaikan perilakunya berdasarkan pengetahuannya. Tentang kecerdasan emosional berkaitan dengan keterampilan emosi, ada enam keterampilan emosi yang esensial, yaitu memahami diri sendiri (selfawareness), mengelola emosi (managing emotions), empati (emphaty), komunikasi (communicating), kerjasama (co-operation), mengatasi konflik (resolving conflicts). Sampai saat ini belum ada paper and pencil test yang sudah tervalidasi dengan baik untuk mengukur kecerdasan emosional sebagaimana halnya IQ (Dulewicz \& Malcolm, 2000).

Ada beberapa dimensi dari kecerdasan emosional yang lebih dikenal dengan sebutan four branch model of emotional intelligence.

1. Persepsi Emosi (Emotional Perception) artinya adalah kemampuan individu untuk mengenali emosi, baik yang dirasakan oleh diri sendiri maupun oleh orang lain.

2. Integrasi Emosi (Emotional Integration) artinya adalah kemampuan individu dalam memanfaatkan sensasi emosi yang dirasakan untuk menghadapi masalahmasalah yang berkenaan dengan sistem kognisi.

3. Pemahaman Emosi (Emotional Understanding) artinya adalah kemampuan individu untuk memahami emosi yang dirasakan dan dapat menggunakan pengetahuan mengenai emosi yang dirasakan untuk mengetahui bagaimana penerapannya dalam kehidupan sehari-hari

4. Pengaturan Emosi (Emotional Management) yang artinya adalah kemampuan individu dalam memadukan data-data mengenai emosi yang dirasakan oleh diri sendiri maupun orang lain untuk menentukan tingkah laku yang paling efektif yang akan ditampilkan pada saat berinteraksi dengan orang lain. (Salovey \& Mayer, 2004)

Mempersiapkan perkembangan kecerdasan emosional anak sangat penting, karena akan menentukan bagaimana anak bertumbuh kembang dengan kecerdasan emosional di tahap perkembangan berikutnya. Pada masa anak-anak, mereka banyak menghadapi berbagai permasalahan baik fisik maupun emosionalnya. yang ditunjukkan lewat tingkahlaku yang dipandang bermasalah.

Beberapa contoh masalah emosional pada anak yang cukup sering menjadi adalah sebagai berikut: Temper tantrum tidak pada usianya, Ekspresi emosi yang tidak tepat, 
Kecemburuan pada sibling yang berlebihan, Sulit ditinggal orang tua untuk bekerja, berebut mainan, Rendahnya ketrampilan sosialisasi, Dikucilkan oleh teman-teman, Tidak peduli dengan orang lain/teman, Bunuh diri pada anak, Bullying di sekolah dan lingkungan bermain, Berkelahi di sekolah.

Pengembangan kecerdasan mental dan emosional bisa dilakukan orang tua dalam setiap aspek kehidupan anak. Gambaran sesuatu yang dialami anak dimasa lalunya menjadi penentu bagaimana mereka bersikap, bertingkah laku, termasuk pola tanggap emosi. Semua pengalaman emosi di masa kanak-kanak dan remaja akan menjadi penentu kecerdasannya. Tanggapan, belaian, maupun bentakan yang menyakitkan dan sebagainya akan masuk ke gudang emosi yang berpusat di otak.

Seperti apa Keadaan emosional anak yang baik antara lain: Mengutarakan perasaan mereka dengan jelas dan langsung, lebih bisa mengendalikan dorongan- dorongan dan keinginan mereka, Tidak didominasi oleh emosi negatif seperti rasa takut, kekhwatiran, rasa bersalah, rasa malu, Kekecewaan, rasa putus asa, merasa tidak berdaya, Ketergantungan, pembohongan, Putus Asa, Bisa menyeimbangkan perasaan dengan alasan, logika, dan kenyataan, Percaya diri, Independen (mandiri), Bisa Memotovasi diri, Mengerti perasaan orang lain, Pembelajar yang baik, Mampu bertahan melawan tekanan, Mampu menyelesaikan konflik dengan baik, Memahami rasa putus asa dengan baik, Tidak terlibat dalam perilaku yang merusak diri seperti narkoba, alcohol, Memiliki lebih banyak teman Di sekolah, mereka lebih baik secara akademis dan mampu menciptakan suasana aman, nyaman, yang membuatnya lebih mudah untuk belajar.

Banyak pendapat yang dikemukakan oleh ahli mengenai konsep pengertian orang tua, yaitu menurut Miami yang dikutip oleh Kartini Kartono, dikemukakan "Orang tua adalah pria dan wanita yang terikat dalam perkawinan dan siap sedia untuk memikul tanggung jawab sebagai ayah dan ibu dari anak-anak yang dilahirkannya." .Menurut Thamrin Nasution, Orang tua adalah setiap orang yang bertanggung jawab dalam suatu keluarga atau tugas rumah tangga yang dalam kehidupan sehari-hari disebut sebagai bapak dan ibu. Ahli psikologi lainnya yaitu Ny. Singgih D Gunarsa dalam bukunya psikologi untuk keluarga menga takan, "Orang tua adalah dua individu yang berbeda memasuki hidup bersama dengan membawa pandangan, pendapat dan kebiasaan- kebiasaan sehari- hari.

Setiap pengalaman yang dilakui anak, baik melalui penglihatan, pendengaran, maupun perlakuan yang diterimanya akan ikut menentukan pembinaan pribadinya. Setiap orang tua tentunya menginginkan memiliki anak yang sehat baik jasmani maupun rohani, untuk mencapai hal tersebut tentunya perlu dilatih dan didik sehingga tercapai apa yang diinginkan.

Orang tua harus bisa mendengar dan memahami perasaan anak, dan hindari untuk memojokkan anak jika ia melakukan kesalahan, Orang tua juga harus dapat memberikan batasan terhadap keinginan anak. "Dan jika ingin memenuhi keinginan anak, sebisanya orang tua memberi persyaratan untuk memacu anak berusaha, menunda keinginan anak, bukan berarti harus menghalangi semua keinginannya, tapi menentukan prioritas kebutuhannya. Biasakan orang tua mengajak anak untuk berdialog dalam upaya menyelesaikan masalah seraya menunjukkan kerugian dari rasa amarah yang berlebihan. Orang tua yang mampu menahan dan mengelola amarahnya dapat menjadi teladan bagi anak, sehingga anak juga dapat menahan rasa amarah mereka jika menemui masalah yang bertentangan dengan kehendaknya.

Orang tua hendaknya mengajarkan anak untuk mendengar aktif sehingga ia terbiasa memahami perasaan orang lain. "Ini penting, karena setiap orang pasti ingin didengar perasaannya. Rasa empati wajib diajarkan kepada anak dengan mempergunakan berbagai kesempatan untuk melihat orang lain dalam beragam keadaan. "Memelihara binatang kesayangan juga dapat memotivasi anak memahami perasaannya dan ini dapat menjadi bekal baginya untuk belajar memahami orang lain. 
Anak yang memiliki kecerdasan emosi sepertinya dapat menjadi jaminan untuk melangkah sukses menguasai dunia di kemudian hari. Artinya, anak akan lebih mudah diterima oleh lingkungan dan teman- temannya serta bermanfaat bagi orang lain. Untuk meningkatkan kecerdasan emosi anak, orang tua harus mampu membentuk pribadi anak dengan mengenalkan kejujuran, tak selalu memenuhi keinginan anak, menahan amarah, membentuk rasa percaya diri, mengajarkan anak mendengar aktif, membentuk anak yang asertif, memiliki rasa empati dan melatih bekerjasama.

Saat anak menginjak dewasa, mereka pasti akan berhubungan dengan orang lain. Untuk itu, melatih anak bekerjasama sejak dini amat penting untuk memupuk kepribadian mereka. Anak yang memiliki bekal yang cukup untuk meningkatkan kecerdasan emosi mereka, nantinya mereka akan lebih mudah bertahan dari badai stres. Tekanan stres juga dapat diatasi dengan mengurangi sensitivitas perasaan anak dan mengajak mereka berpikir lebih realistis dan positif.

Hasil penelitian menunjukkan bahwa, perkembangan sel otak terpesat pada anak terjadi pada masa balita, sehingga pada masa ini sering disebut masa keemasan golden age. Untuk itu, perlu merangsang aktivitas kegiatan yang dapat merangsang otak dan memberikan nutrisi otak sehingga dapatdengan berkembang pesat. Orang tua sangat berperan dalam mendorong kecerdasan anak dengan cara memberikan stimulasi. Karena di usia balita anak. Anak banyak menghabiskan waktu di lingkungan rumahnya, orang tua harus lebih kreatif memanfaatkan kondisi keseharian sebagai media belajar.

Menurut Conny Semiawan dan kawan-kawan, bahwa, "Orang tua perlu membina anak agar mau berprestasi secara optimal, karena kalau tidak berarti suatu penyia-nyiaan terhadap bakatnya. Pembinaan dilakukan dengan mendorong anak untuk mencapai prestasi yang sesuai dengan kemampuannya. Banyak kasus yang mengidentifikasikan bahwa orang tua tidak peka terhadap bakat dan kemampuan anak, sebagai imbasnya potensi yang ada pada anak tersebut tidak dapat berkembang dengan optimal.

Dalam kaitannya dengan mengembangka kecerdasan emosional anak, peran orang tua sangat penting, orang tua setahap demi setahap dapat merekayasa pengalaman-pengalaman yang dapat membesarkan hati anak dan memungkinkan koreksi atas temperamen anak. Agar anak mampu mengontrol emosinya dan menjaga agar tindakannya tidak dikendalikan emosi semata, anak harus diajarkan memahami apa yang yang diharapkan dari dirinya serta dilatih untuk memahami orang lain. Perlu diberi pemahaman bahwa segala tindakannya akan membawa konsekuensi baik pada dirinya maupun orang lain. Makin sering anak berlatih mengelola emosi, seperti meredakan marah atau kecewa, maka semakin terlatih ia dalam mengelola emosi. Selain itu, orang tua juga perlu berhati-hati karena seperti juga kecerdasan kognitif, kecerdasan emosi merupakan kondisi yang netral secara normal. Jadi, hendaknya orang tua selalu menggunakan "kompas moral" dalam membimbing si kecil.

Kecerdasan emosional bukanlah sesuatu yang dimiliki seorang anak secara genetis atau bawaan. Akan tetapi, merupakan sesuatu yang dapat dipelajari dan dikembangkan (Dulewicz \& Malcolm, 2000). Oleh karena itu, perlu dilakukan upaya-upaya yang dapat mengembangkannya secara sehat agar masa- masa yang akan datang lahir generasi yang lebih baik daripada generasi sekarang. Penyair Khalil Gibran mengibaratkan seorang anak seperti anak panah yang telah lepas dari busurnya dan dia adalah milik sang hidup itu sendiri, tidak diartikan secara 'harafiah' bahwa anak setelah lahir dibiarkan begitu saja. Akan tetapi, di dalam kelepasannya itu tetap ada peran orang tua untuk mendidik dan mengarahkan. Apalagi bila dikaitkan dengan realitas bahwa anak dalam kesehariannya terus melakukan interaksi dengan kedua orang tuanya.

Beberapa faktor yang perlu dikembangkan orang tua dalam kaitanya dengan kecerdasan emosional anak yaitu: 
1. Melatih anak untuk mengenali emosi diri

Mengenali emosi diri merupakan dasar dari kemampuan kecerdasan emosional. Dalam psikologi hal tersebut dikenal dengan metamood yakni kesadaran seseorang akan emosinya sendiri, menurut Mayer, kewaspadaan terhadap sesuatu hati atau pikiran tentang suasana hati jika tidak dilatih maka akan mudah sekali membawa seseorang ke dalam aliran emosi yang dikuasai oleh emosi. Adanya kesadaran diri tidaklah menjamin penguasaan emosi, tetapi merupakan salah satu persyaratan penting untuk mengendalikan emosi sehingga individu dapat dengan mudah menguasai emosinya.

2. Melatih anak untuk mengelola emosi

Mengelola emosi merupakan kemampuan individu untuk menangani perasaan agar dapat terungkap dengan tepat atau selaras sehingga tercapai keseimbangan dalam diri individu, menjaga agar emosi yang merisaukan terkendali merupakan kunci menuju kesejahteraan emosi.

3. Melatih anak memotivasi diri sendiri

Dengan dimilikinya motivasi dalam diri individu berarti memiliki ketekunan untuk menahan diri mengendalikan dorongan hati serta mempunyai perasaan motivasi yang positif yaitu: antusiasme, optimis

4. Melatih anak untuk mengenali emosi orang lain

Kemampuan untuk mengenal emosi orang lain disebut juga empati, menurut Goleman kemampuan seseorang untuk mengenali orang lain atau peribadi merupakan kemampuan empati seseorang. Individu yang memiliki kemampuan empati lebih mampu menangkap sinyal-sinyal sosial yang tersembunyi yang mengisyaratkan apa- apa yang dibutuhkan sehingga ia memiliki kemampuan menerima sudut pandang orang lain, peka terhadap perasaan orang lain dan memiliki kemampuan untuk mendengarkan orang lain

Di dalam Alqur'an dijelaskan beberapa cara untuk mendidik anak antara lain: Artinya: "(Lukman berkata) : Wahai anakku, dirikanlah shalat dan surhlah (manusia) mengerjakan yang baik dan ceagahlah (mereka) dari perbutan yang munkar dan bersabarlah terhadap apa yang menimpa kamu. Sesungguhnya yang demikian itu termasuak hal-hal yang diwajibkan (oleh Allah)". (QS. Luqman: 17).

1. Membina Pribadi Anak

Orang tua adalah pembinaan pribadi yang pertama dalam hidup anak. Kepribadian orang tua, sikap dan cara hidup mereka, merupakan unsur-unsur pendidikan yang secara tidak langsung akan masuk ke dalam pribadi anak yang sedang tumbuh. Banyak pula pengalaman-pengalaman anak, yang mempengaruhi nilai pendidikan baginya, yaitu pembinaan- pembinaan tertentu yang di lakukan orang tua terhadap anak, Sikap anak terhadap guru agama dan pendidikan agama di sekolah sangat dipengaruhi oleh sikap orang tuanya terhadap agama dan guru agama khususnya. Pengalaman yang di bawa oleh anakanak dari rumah itu, akan menentukan sikapnya terhadap pergaulan sehari-hari di luar Di samping pendidikan dan pengajaran yang dilaksanakan dengan sengaja oleh guru dalam pembinaan anak didik, sangat berpengaruh dalam proses pembinaan pribadi anak.

2. Membentuk kebiasaan

Latihan-latihan keagamaan yang menyangkut ibadah, seperti sembahyang, doa, membaca Alquran atau menghafal ayat/surat pendek, shalat berjamaah di sekolah dan di masjid harus dibiasakan sejak kecil, sehingga lambat laun akan tumbuh rasa senang melakukan ibadah tersebut. Anak dibiasakan sedemikian rupa, sehingga dengan sendirinya akan terdorong untuk melakukannya, tanpa suruhan dari luar. Dengan kata lain dapat kita sebutkan bahwa pembiasaan dalam pendidikan anak sangat penting, terutama dalam pembentukkan pribadi, akhlak dan agama pada umumnya, karena pembiasaan-pembiasaan agama itu akan memasukkan unsur-unsur positif dalam pribadi yang sedang tumbuh. Semakin banyak 
pengalaman agama yang didapatnya melalui pembiasaan itu, akan semakin banyaklah unsur agama dalam pribadinya. Dengan demikian, dapat dikatakan bahwa pendidikan pembiasaan itu sangat penting dalam mendidik anak, terutama dalam pendidikan agama.

Keadaan emosional terbaik untuk anak-anak adalah kondisi yang penuh dengan kebahagiaan dan antusiasme. Ini adalah suatu keadaan di mana mereka memiliki hubungan interpersonal yang harmonis. Pada keadaan ini, mereka mengembangkan semua potensi mereka, menempatkan semua keterampilan dan bakat untuk digunakan secara penuh

\section{Simpulan dan Saran}

Masa anak adalah masa yang sangat rentan terhadap hal-hal negatif yang dapat mengganggu perkembangan individu. Cukup banyak masalah-masala-hmasalah emosional pada anak yang menjadi keluhan orang tua, seperti temper tantrum tidak pada usianya, ekspresi emosi yang tidak tepat, kecemburuan pada sibling yang berlebihan, atau sulit ditinggal orang tua untuk bekerja. Kunci untuk mengatasinya adalah dengan mengenalkan anak akan perasaannya maupun ekspresi perasaannya.

Melatih anak untuk mengenali perasaannya, mengintegrasikan perasaan- perasaannya, serta memahami perasaannya akan membantu anak dalam bersosialisasi dengan orang lain. Anak dilatih pula untuk berempati dengan orang lain sehingga mudah baginya untuk bergaul serta bersosialisasi dengan oran. Selain itu, orang tua harus menyadari bahwa ia adalah figur panutan bagi anak.

\section{Daftar Pustaka}

Dulewicz, V., \& Malcolm, H. (2000). Emotional Intelligence You can't Afford to Ignore It . Retrieved from ASE: http://www.ase- solutions.co.ak/ei/Default. htm

Gardner, H. (1993). Multiple Intelligences ; The Theory In Practice. New York: Basic.

Goleman, D. (2000). Emotional Intelligence (Terjemahan). Jakarta: Gramedia Pustaka Utama.

Salovey, P. B., \& Mayer, M. (2004). Emotional Intelligence. New York: National Professional Resources, Inc. Atkinson \& Atkinson. Pengantar Psikologi, edisi kesebelas. Batam: Interaksara.1998

Hall, Lindzey \& Campbell. Theories of Personality, fourth edition. New York: John Wiley \& Sons, Inc. 1998

Hurlock, Elizabeth. B. Developmental Psychology A life-Span Approach, fifth edition. New Delhi: Tata McGraw-Hill Publishing Company Ltd.1990

McCluskey, Alan. Emotional Intelligence in Schools (http://www. connected.org/lern/school.htm). 1997

Saphiro, Lawrence, E. Mengajarkan Emosional Intelligence Pada Anak, Jakarta: Gramedia, 1998 